\title{
Edaphic algae are an important component of salt marsh food-webs: evidence from multiple stable isotope analyses
}

\author{
Michael J. Sullivan, Cynthia A. Moncreiff \\ Department of Biological Sciences, PO Drawer GY, Mississippi State University, Mississippi State, Mississippi 39762, USA
}

\begin{abstract}
Carbon, sulfur, and nitrogen stable isotope ratios were measured in an irregularly flooded Mississippi, USA, salt marsh to evaluate the relative importance of vascular plants and algae in the food web. Primary producers had distinct $\delta^{13} \mathrm{C}$ values: Spartina alterniflora (hereafter Spartina) $(-13 \%)$, Juncus roemerianus (hereafter Juncus) $(-26 \%)$, and edaphic algae $(-21 \%)$. A pure zooplankton sample, which should closely approximate the phytoplankton, had a $\delta^{13} \mathrm{C}$ value of $-23 \%$. Values for $\delta^{34}$ S ranged from 0 to $+2 \%$ for vascular plants, while those for edaphic algae and zooplankton were +14 and $+11 \%$, respectively; $\delta^{15} \mathrm{~N}$ for all primary producers ranged from +5 to $+6 \%$. For 49 of the $56(88 \%)$ consumers sampled, $\delta^{13} \mathrm{C}$ fell within a range of -22 to $-18 \%$; this range centered around edaphic algae and zooplankton, but was distinct from the $\delta^{13} \mathrm{C}$ of Spartina and Juncus. Values of $\delta^{34} \mathrm{~S}$ for 48 of the 56 $(86 \%)$ estuarine consumers ranged from +9 to $+16 \%$, which included edaphic algae and zooplankton but was 8 to $15 \%$ more enriched in ${ }^{34} \mathrm{~S}$ than Spartina or Juncus. Dual isotope plots showed the fauna to tightly cluster around values for edaphic algae and zooplankton; no consumer even moderately resembled Spartina or Juncus. This strongly suggests that the ultimate food sources for this marsh's invertebrate and fish fauna are the benthic and planktonic algae; direct contributions from vascular plants appear to be minor.
\end{abstract}

\section{INTRODUCTION}

The great productivity of coastal salt marshes supports a diverse array of consumers which exhibit a variety of feeding modes. The major contributors to this productivity are the highly visible vascular plants and microscopic edaphic and planktonic algae. The edaphic algae includes diatoms, green, yellow-green, and blue-green algae inhabiting exposed and subtidal sediments of tidal creeks, as well as those associated with the sediments beneath the extensive and dense canopy of vascular plants on the marsh proper. Despite their small size, the edaphic algae exhibit significant primary production rates (Sullivan \& Moncreiff 1988 and references cited therein). The ratio of annual edaphic algal to vascular plant net aerial production (EAP/VPP) typically ranges from 8 to $33 \%$ in coastal salt marshes of the Atlantic and Gulf Coasts of the USA. However, an EAP/VPP value of $61 \%$ was reported by Sullivan \& Moncreiff (1988) in the Scirpus olneyi Gray zone of a Mississippi marsh and Zedler (1980) found values of 76 to $140 \%$ in 4 vascular plant zones of a
California marsh. Furthermore, benthic microalgae may greatly augment the primary production of the water column in well-mixed shallow estuaries via their resuspension (Shaffer \& Sullivan 1988).

Until relatively recently, it was universally assumed that salt marsh vascular plants supported food webs both within the marsh itself and in adjacent estuarine waters via a detritus-based pathway. However, stable carbon isotope work carried out in Georgia salt marshes (Haines 1976a, 1977) showed that the isotopic signature of detritus in tidal creeks did not match that of the dominant vascular plant Spartina alterniflora Loisel (hereafter Spartina). This unexpected finding began an extensive re-examination of the long-standing dogma that Spartina was a major component in the food web after it died and then decomposed. Subsequent work (Haines 1976b, Haines \& Montague 1979, Hackney \& Haines 1980, Sherr 1982, Hughes \& Sherr 1983, Mariotti et al. 1983, Schwinghamer et al. 1983, Jackson et al. 1986) in salt marshes has amplified and extended this earlier work with different investigators claiming varying importance of Spartina and algal car- 
bon as food sources. In all of these studies, a single isotope approach was utilized, and the benthic algae were either ignored, emphasized as a possible food source for selected consumers, or were lumped together with phytoplankton in discussions of the importance of algal carbon.

Peterson and co-workers $(1985,1986)$ were first to apply multiple stable isotopes (carbon, sulfur, and nitrogen) to the study of salt marsh food-webs. Dual isotope plots led to the conclusion that the fauna of a Massachusetts marsh were more dependent on Spartina than on phytoplankton, but they did not consider the benthic algae as a potential food source. Later multiple isotope work in a Georgia salt marsh (Peterson \& Howarth 1987) led to the conclusion that assimilation of Spartina and algal carbon by consumers was approximately equal, and the possibility that edaphic algae might be important was stressed.

The present study has taken the multiple stable isotope approach to a Gulf Coast, USA, salt marsh. This was done to extend regional comparisons beyond the Atlantic coast of the United States and because of our belief that the importance of benthic algae in salt marsh food webs has been underestimated.

\section{MATERIALS AND METHODS}

Study area. All field work was conducted in Graveline Bay Marsh, Mississippi, USA, $\left(30^{\circ} 21^{\prime} 26^{\prime \prime} \mathrm{N}\right.$, $88^{\circ} 40^{\prime} 59^{\prime \prime} \mathrm{W}$, located ca $11 \mathrm{~km}$ southeast of the Gulf Coast Research Laboratory at Ocean Springs. The Graveline system is irregularly flooded with a mean tidal range of $0.6 \mathrm{~m}$; inputs of freshwater are minimal. The dominant vascular plants are Spartina and Juncus roemerianus Scheele (hereafter Juncus). The production rates of the edaphic algae on the marsh proper (Sullivan \& Moncreiff 1988) and the phytoplankton and subtidal microalgae of tidal creeks (Zimba unpubl. data) have been determined.

Sampling strategy. Floral and faunal samples for stable isotope analysis were collected during March, May, June, July, September, and October of 1987 and January, April, June, August, and September of 1988. The sampling effort was concentrated at three stations. Stn 1 was located near the upper end of Graveline Bayou; Stn 2 was approximately at the mid-point of the bayou; and Stn 3 was immediately upstream of the mouth. The 3 stations were floristically similar in terms of vascular plant composition.

Sample collection. Vascular plants (Spartina and Juncus) were carefully procured in the field to prevent contamination by the introduction of foreign material to the samples. Only living, aboveground biomass was collected. Benthic algae were collected whenever pos- sible; samples were removed from the marsh surface with care to exclude as much non-algal material as conditions would permit. All plant samples were frozen if immediate processing was not possible.

Samples for zooplankton were collected on most sampling dates, with a concentrated effort on 13 January 1988. Plankton nets with mesh sizes of 335,153 , and $28 \mu \mathrm{m}$ were towed for a maximum of $10 \mathrm{~min}$. Collections were placed on ice and later frozen until processed.

Consumers (polychaetes, bryozoans, bivalves, gastropods, crustaceans, and a variety of fish species) were collected from as many habitats and trophic levels as possible. Animals were collected by hand or with dredges, seines, trawls, and gill nets as appropriate. Only live, intact organisms were taken to minimize contamination by shell or other foreign material. All samples were placed in clean plastic bags or containers, labelled as to date and location of collection, and placed on ice for transport to the laboratory, where they were frozen for future processing if immediate preparation was not possible.

Sample processing. All biological materials were washed with $10 \% \mathrm{HCl}$ to remove carbonate contaminants followed by repeated rinses with tap water to a neutral $\mathrm{pH}$ and a final rinse with distilled water. Excess moisture was removed from samples by gentle vacuum filtration on glass-fiber filter paper. Samples were then oven-dried to constant weight at $60^{\circ} \mathrm{C}$. Zooplankton were carefully separated from particulate material using a saturated $\mathrm{NaCl}$ solution; plankton floated on the surface with the majority of the detritus sinking to the bottom of the processing container. Using a dissecting microscope, all remaining visible detrital material was manually separated from the zooplankton to obtain as pure a sample as possible. Consumer samples were handled to minimize contamination with foreign material. Whenever possible, only muscle tissue was used to obtain consistent and comparable samples for each species. Final processing was essentially identical for all sample types. Dried samples were powdered using either a Wiley Mill equipped with a \#40 delivery tube or ground with a mortar and pestle to as fine a consistency as possible.

The actual measurements of stable isotope ratios for all samples were performed by Coastal Science Laboratories of Austin, Texas. The accuracy of the $\delta^{13} \mathrm{C}$, $\delta^{34} \mathrm{~S}$, and $\delta^{15} \mathrm{~N}$ analyses was $0.2,0.5$, and 0.2 parts per mil $(\%)$, respectively. A blind control was included with each set of samples to the commercial firm to test the repeatability of the determinations.

Stable isotope terminology and background. Stable isotope ratios are reported with reference to a standard (Fry \& Sherr 1984). The difference between the material under consideration and the standard is 
expressed in parts per thousand or per mil (\%) according to the following formula:

$$
\delta \mathrm{X}=\left[\left(\mathrm{R}_{\text {sample }} / \mathrm{R}_{\text {standard }}\right)-1\right] \times 10^{3},
$$

where $\mathrm{X}$ is ${ }^{13} \mathrm{C},{ }^{34} \mathrm{~S}$, or ${ }^{15} \mathrm{~N}$, and $\mathrm{R}$ is ${ }^{13} \mathrm{C} /{ }^{12} \mathrm{C},{ }^{34} \mathrm{~S} /{ }^{32} \mathrm{~S}$, or ${ }^{15} \mathrm{~N} /{ }^{14} \mathrm{~N}$. The standards for $\mathrm{C}, \mathrm{S}$, and $\mathrm{N}$ are Peedee Belemnite, Canyon Diablo troilite, and atmospheric diatomic nitrogen, respectively.

Biological materials are usually depleted in ${ }^{13} \mathrm{C}$ relative to the PDB standard and hence have negative $\delta^{13} \mathrm{C}$ values (Fry \& Sherr 1984). Unlike $\delta{ }^{13} \mathrm{C}$ values, those of $\delta^{34} \mathrm{~S}$ may be positive or negative in the tissues of estuarine plants and animals. Estuarine plants will have positive values if they take up their inorganic sulfur primarily as ionic sulfate and negative if their main sulfur source is inorganic sulfide (Fry et al. 1982). In contrast to carbon and sulfur, few $\delta^{15} \mathrm{~N}$ values exist for salt marsh flora and fauna. All reported values for marsh plants have been positive.

\section{RESULTS}

\section{Stable isotope ratios of producers}

The stable carbon isotope ratios of the vascular plants and edaphic algae were distinct (Table 1). The $\mathrm{C}_{4}$ plant Spartina had $\delta^{13} \mathrm{C}$ values that exhibited very little seasonal variation $(-13.9$ to $-12.8 \%$ with an average value of $-13.2 \%$. For the $C_{3}$ plant Juncus, $\delta^{13} \mathrm{C}$ ranged from -26.6 to $-24.8 \%$ with an average value of $-25.5 \%$. The composite sample of edaphic algae had a $\delta^{13} \mathrm{C}$ value of $-20.6 \%$. Samples of filamentous algae collected in the bayou yielded the following $\delta^{13} \mathrm{C}$ values: Bostrychia radicans Montagne $(-26.2 \%)$, Vaucheria sp. $(-19.3 \%)$, Ectocarpus sp. $(-18.7 \%)$, and Enteromorpha sp. $(-18.4 \%)$. Excepting the very low value for the red alga $B$. radicans, $\delta^{13} \mathrm{C}$ ranged from -20.6 to $-18.4 \%$ for the benthic algae of Graveline Bay Marsh. It was not possible to collect a pure phytoplankton sample but a pure zooplankton sample was obtained; its $\delta^{13} \mathrm{C}$ value was $-23.3 \%$.

Stable sulfur isotope ratios were more variable than those of carbon (Table 1). The average $\delta^{34} \mathrm{~S}$ value for
Spartina was $+1.4 \%$ but such values ranged from -8.5 to $+13.9 \%$ over an annual cycle. However, with the exception of 2 high values, $\delta^{34} \mathrm{~S}$ was always less than $+8 \%$. The range in $\delta^{34} \mathrm{~S}$ for Juncus $(-4.8$ to $+5.4 \%)$ was less than that for Spartina, with an average value of $+0.4 \%$ being recorded for the former. The edaphic algae composite had a $\delta^{34} \mathrm{~S}$ value of $+14.3 \%$ whereas the pure zooplankton sample was more depleted in ${ }^{34} \mathrm{~S}$ with a value of $+10.7 \%$. A single collection of the brown alga Ectocarpus sp. yielded a value of $+13.1 \%$.

Stable nitrogen isotope values ranged from +3.4 to $+6.7 \%$ and +3.7 to $+7.3 \%$ for Spartina and Juncus, respectively. Mean $\delta^{15} \mathrm{~N}$ values for these two vascular plants were +5.2 and $+5.3 \%$, respectively (Table 1 ). The edaphic algae composite had a $\delta^{15} \mathrm{~N}$ value of $+6.1 \%$ whereas the pure zooplankton sample was $+7.1 \%$. Samples of filamentous algae collected in the bayou yielded the following values: Vaucheria sp. $(+4.7 \%)$, Bostrychia radicans $(+6.5 \%)$, Enteromorpha sp. $(+9.0 \%)$, and Ectocarpus sp. $(+10.6 \%)$.

\section{Stable isotope ratios of consumers}

Table 2 and Fig. 1 summarize the $\delta^{13} \mathrm{C}$ data for consumers sampled in the Graveline Bay Marsh system. Forty-nine of the $56(88 \%) \delta^{13} \mathrm{C}$ values listed in Table 2 fell within a range of -22 to $-18 \%$. Of these 49 consumers, 34 fell within an even narrower range of -22 to $-20 \%$. The largemouth bases Micropterus salmoides, which was collected from the head of the Graveline system, had the lowest $\delta^{13} \mathrm{C}$ value of $-25 \%$, whereas deposit-feeding $U_{C a} \mathrm{spp}$. (fiddler crabs) had the highest $(-15 \%)$ of any consumer. The pure zooplankton sample possessed one of the lowest $\delta^{13} \mathrm{C}$ values $(-23 \%)$ of any consumer. Filter-feeding bivalves (Polymesoda caroliniana, Rangia cuneata, Ischadium recurvum, Geukensia demissa, and Crassostrea virginica) exhibited a very narrow range of -22 to $-21 \%$; this range is slightly more enriched in ${ }^{13} \mathrm{C}$ than zooplankton in the Graveline system.

The range in $\delta^{34} \mathrm{~S}$ values $(+6$ to $+16 \%$ ) for marsh consumers was the greatest of the 3 isotope ratios (Table 2, Fig. 2). Values of $\delta^{34} \mathrm{~S}$ for 48 of $56(86 \%)$ consumers

Table 1. Summary of $\delta^{13} \mathrm{C}, \delta^{34} \mathrm{~S}$, and $\delta^{15} \mathrm{~N}$ values for primary producers and zooplankton of Graveline Bay Marsh in parts per mil $(\%)$. Each mean is followed by its standard error and the number of samples $(\mathrm{N})$

\begin{tabular}{|lccc|}
\hline Producers & $\delta^{13} \mathrm{C}$ & $\delta^{34} \mathrm{~S}$ & $\delta^{15} \mathrm{~N}$ \\
\hline Spartina & $-13.2 \pm 0.1(12)$ & $+1.4 \pm 2.2(12)$ & $+5.2 \pm 0.5(6)$ \\
Juncus & $-25.5 \pm 0.2(12)$ & $+0.4 \pm 0.8(12)$ & $+5.3 \pm 0.8(4)$ \\
Edaphic algae & $-20.6(1)$ & $+14.3(1)$ & $+6.1(1)$ \\
Zooplankton & $-23.3(1)$ & $+10.7(1)$ & $+7.1(1)$ \\
\hline
\end{tabular}


Table 2. Summary of stable isotope ratios for consumers of Graveline Bay Marsh. Numbers for $\mathrm{C}, \mathrm{S}$ and $\mathrm{N}$ indicate number of samples. Values are in parts per mil $(\%) ;-$ : no analyses performed

\begin{tabular}{|c|c|c|c|c|c|}
\hline Consumer & $\mathrm{S}^{13} \mathrm{C}$ & $\delta^{34} \mathrm{~S}$ & $\delta^{15} \mathrm{~N}$ & $\mathrm{C}, \mathrm{S}$ & $\mathrm{N}$ \\
\hline Micropterus salmoides (largemouth bass) & -25.1 & 3.6 & 6.7 & 1 & 1 \\
\hline Micropogon undulatus roe & -23.4 & 7.4 & 8.1 & 1 & 1 \\
\hline Trinectes maculatus (hogchoker) & -23.3 & 8.1 & - & 2 & - \\
\hline Zooplankton, all species & -23.3 & 10.7 & 7.1 & 1 & 1 \\
\hline Micropogon undulatus (Atlantic croaker) & -22.4 & 10.9 & 10.2 & 13 & 6 \\
\hline Polymesoda caroliniana (marsh clam) & -22.0 & 11.3 & 8.5 & 1 & 1 \\
\hline Lagodon rhomboides (pinfish) & -22.0 & 12.4 & 10.1 & 7 & 4 \\
\hline Rangia cuneata & -21.9 & 12.0 & 7.2 & 1 & 1 \\
\hline Ischadium recurvum (hooked mussel) & -21.9 & 12.4 & 6.6 & 6 & 4 \\
\hline Geukensia demissa (ribbed mussel) & -21.8 & 11.2 & 7.3 & 2 & 2 \\
\hline Littorina irrorata (marsh periwinkle) & -21.6 & 14.3 & - & 4 & - \\
\hline Crassostrea virginica (American oyster) & -21.4 & 13.9 & 8.1 & 6 & 3 \\
\hline Brevoortia patronus (Gulf menhaden) & -21.3 & 14.5 & 11.3 & 7 & 6 \\
\hline Elops saurus (ladyfish) & -21.3 & 10.5 & - & 2 & - \\
\hline Archosargus probatocephalus (sheepshead) & -21.2 & 12.4 & 10.0 & 6 & 6 \\
\hline Pogonias cromis (black drum) & -21.1 & 8.2 & 8.4 & 1 & 1 \\
\hline Brevoortia patronus roe & -21.1 & 14.0 & 10.0 & 1 & 1 \\
\hline Leiostomus xanthurus (spot) & -21.0 & 9.9 & 11.2 & 7 & 7 \\
\hline Penaeus setiferus (white shrimp) & -21.0 & 9.9 & - & 15 & - \\
\hline Neanthes spp. (nereid worms) & -20.9 & 8.2 & 8.2 & 1 & 1 \\
\hline Anguinella palmata (bryozoan) & -20.8 & 13.5 & 8.1 & 1 & 1 \\
\hline Stellifer lanceolatus (star drum) & -20.8 & 11.5 & 10.2 & 1 & 1 \\
\hline Cynoscion nebulosus (speckled trout) & -20.7 & 12.2 & 11.8 & 11 & 1 \\
\hline Mugil cephalus roe & -20.6 & 10.8 & 7.1 & 1 & 1 \\
\hline Anchoa mitchilli (bay anchovy) & -20.6 & 14.5 & 12.0 & 3 & 2 \\
\hline Penaeus aztecus (brown shrimp) & -20.5 & 10.7 & - & 10 & - \\
\hline Cynoscion arenarius, larval/juv. (white trout) & -20.4 & 12.8 & 11.0 & 2 & 2 \\
\hline Bugula sp. (bryozoan) & -20.4 & 14.0 & 8.9 & 1 & 1 \\
\hline Arius felis (hardhead catfish) & -20.3 & 12.7 & 11.5 & 11 & 7 \\
\hline Brevoortia patronus, larval & -20.3 & 10.0 & - & 3,2 & - \\
\hline Membras/Menidia, juv. & -20.2 & 13.6 & - & 1 & - \\
\hline Lolliguncula brevis (estuarine squid) & -20.2 & 13.2 & 11.1 & 2 & 2 \\
\hline Menidia beryllina (tidewater silverside) & -20.2 & 12.3 & 11.2 & 10 & 7 \\
\hline Membras martinica (rough silverside) & -20.2 & 16.0 & 11.9 & 3 & 1 \\
\hline Larval clupeids & -20.1 & 15.4 & 11.5 & 3 & 3 \\
\hline Paralichthys lethostigma (southern flounder) & -20.0 & 10.9 & 9.7 & 6 & 2 \\
\hline Sciaenops ocellatus (redfish) & -20.0 & 9.8 & 10.2 & 9 & 7 \\
\hline Symphurus plagiusa (blackcheek tonguefish) & -20.0 & 9.3 & - & 1 & - \\
\hline Membras martinica, larval/juv. & -20.0 & 14.4 & 11.5 & 1 & 1 \\
\hline Clibanarius vittatus (striped hermit crab) & -19.6 & 14.2 & 9.4 & 2 & 1 \\
\hline Callinectes sapidus (blue crab) & -19.6 & 10.7 & 8.6 & 10 & 5 \\
\hline Anchoa nasuta (longnose anchovy) & -19.5 & 14.0 & 12.4 & 1 & 1 \\
\hline Bairdiella chrysura (silver perch) & -19.4 & 13.1 & 12.2 & 7 & 4 \\
\hline Paleomonetes pugio (grass shrimp) & -19.4 & 6.2 & 8.6 & 4,3 & 2 \\
\hline Mugil cephalus, juv. & -19.3 & 10.3 & 6.4 & 2 & 1 \\
\hline Fundulus pulvereus (bayou killifishj & -19.1 & 7.3 & 7.8 & 1 & 1 \\
\hline Mugil cephalus (stnped mullet) & -18.9 & 10.3 & 8.0 & 7 & 1 \\
\hline Menticirrhus sp. (kingfish) & -18.8 & 11.5 & 11.1 & 1. & 1 \\
\hline Sciaenops ocellatus, juv. & -18.7 & 12.9 & - & 1 & - \\
\hline Fundulus majalis (longnose killifish) & -18.6 & 7.8 & 9.6 & 3 & 2 \\
\hline Larval spot/croaker & -18.6 & 14.6 & - & 1 & - \\
\hline Poecilia latipinna (sailfin molly) & -18.1 & 10.0 & 6.2 & 1 & 1 \\
\hline Fundulus grandis (Gulf killifish) & -18.1 & 9.6 & - & 1 & - \\
\hline Polinices duplicatus (moon snail) & -18.1 & 10.5 & 8.4 & 1 & 1 \\
\hline Harengula pensacolae (scaled sardine) & -17.8 & 16.4 & 12.1 & 1 & 1 \\
\hline Uca spp. (fiddler crabs) & -15.0 & 14.9 & 7.2 & 1 & 1 \\
\hline
\end{tabular}


Fig. 1. $\delta^{13} \mathrm{C}$ values of consumers in Graveline Bay Marsh

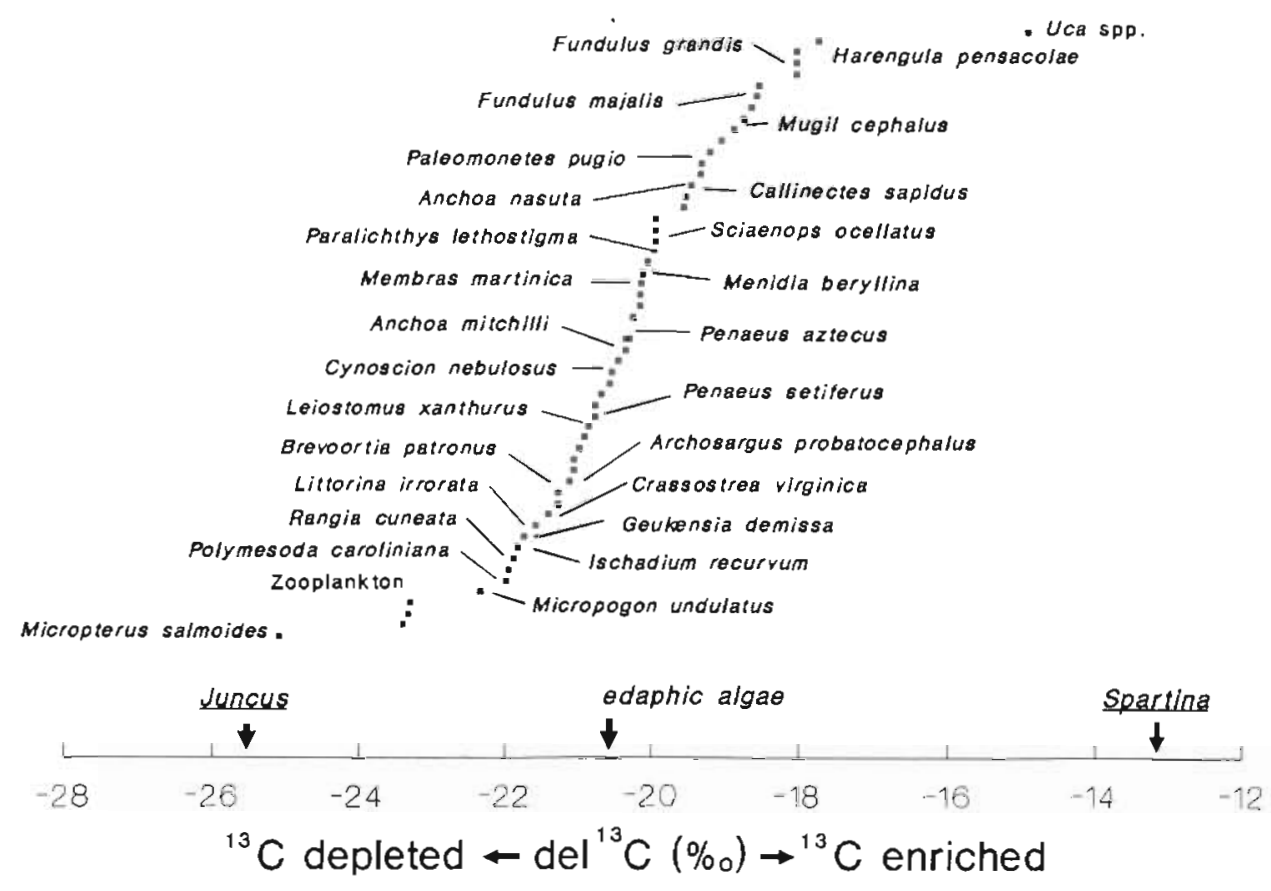

Fig. 2. $\delta^{34} \mathrm{~S}$ values of consumers in Graveline Bay Marsh

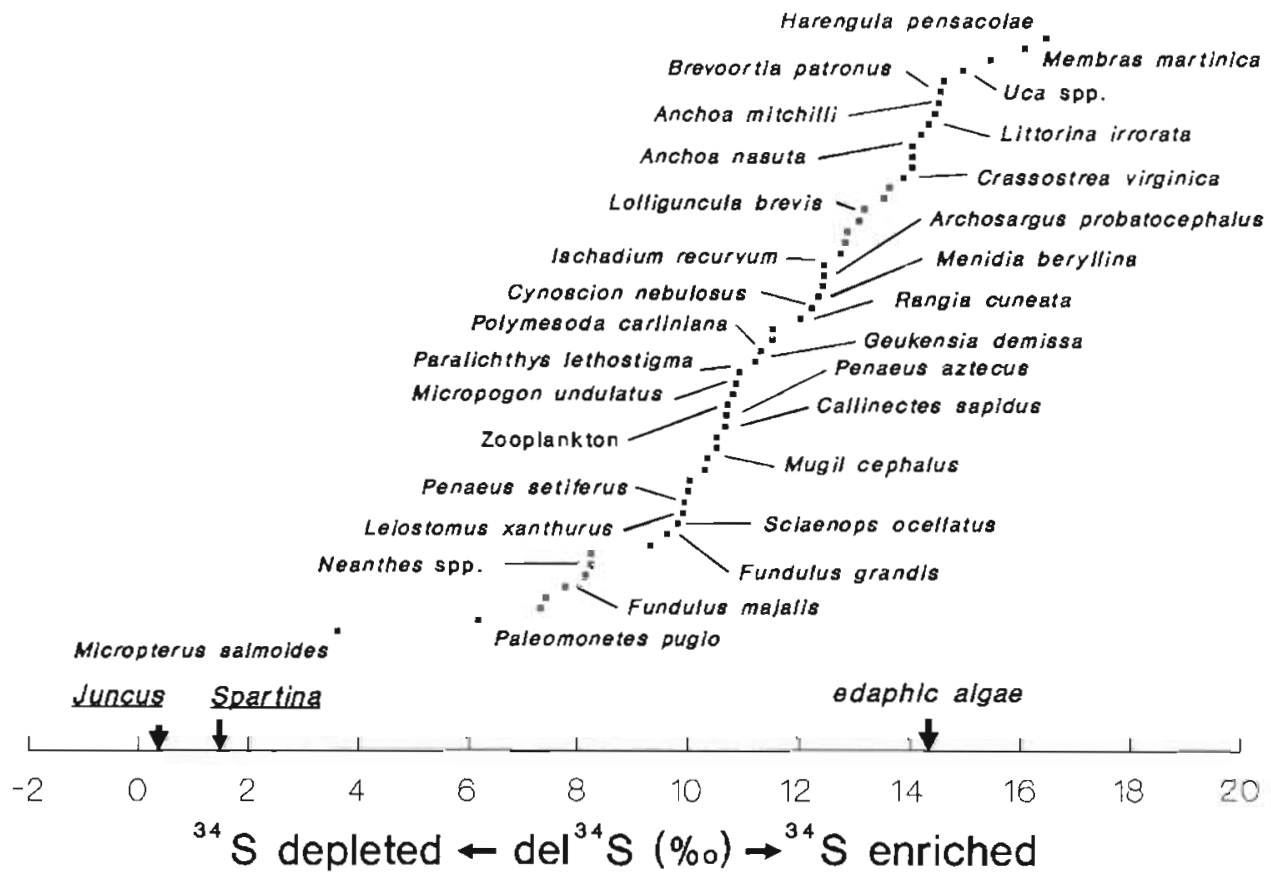

Dual isotope plots

ranged from +9 to $+16 \%$. The freshwater bass Micropterus salmoides was an outlier with a $\delta^{34} \mathrm{~S}$ value of $3.6 \%$.

Table 2 and Fig. 3 summarize the $\delta^{15} \mathrm{~N}$ data for consumers; such data was obtained for 45 of the 56 consumer categories. $\delta^{15} \mathrm{~N}$ for the fauna ranged from +6 to $+12 \%$; thus consumers were enriched in ${ }^{15} \mathrm{~N}$ relative to edaphic algae, vascular plants, and zooplankton. As a group, invertebrates had lower $\delta^{15} \mathrm{~N}$ values than did the fish species sampled.
Dual isotope plots of $\delta^{13} \mathrm{C}$ vs $\delta^{34} \mathrm{~S}$ (Fig. 4) and $\delta^{13} \mathrm{C}$ vs $\delta^{15} N$ (Fig. 5) were generated from the pool of stable isotope data. Each plot includes the stable isotope values for the consumer categories listed in Table 2 in addition to those of Spartina, Juncus, and edaphic algae. Error bars were not plotted since only a single value for the edaphic algae was obtained. A plot of 


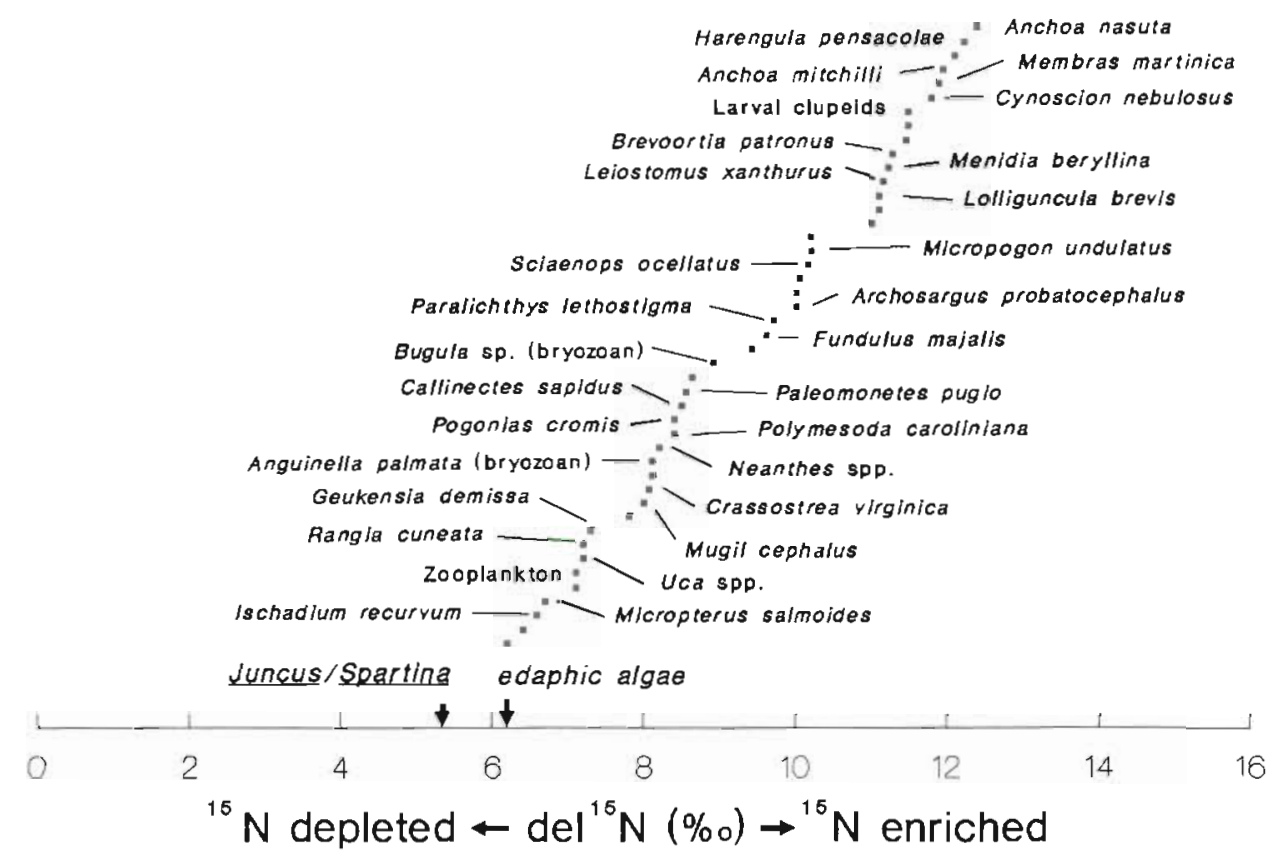

Fig. 3. $\delta^{15} \mathrm{~N}$ values of consumers in Graveline Bay Marsh

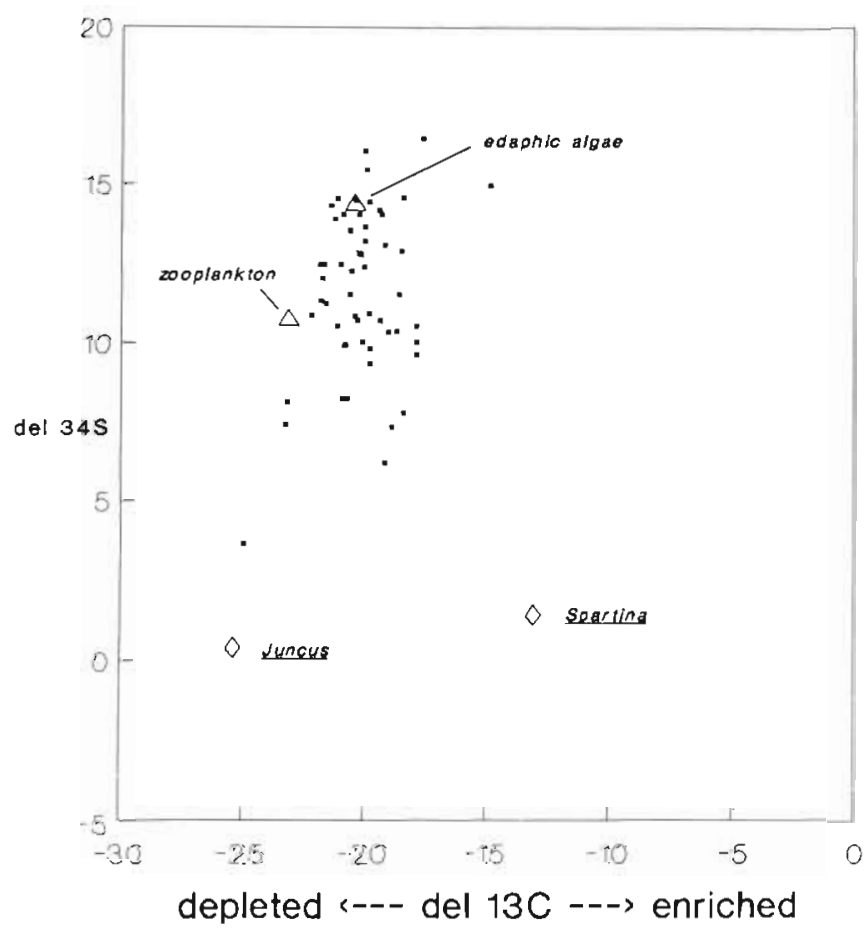

Fig. 4. Plot of $\delta^{13} \mathrm{C}$ vs $\delta^{34} \mathrm{~S}$ values for primary producers and consumers in Graveline Bay Marsh in parts per mil (\%)

$\partial^{34} \mathrm{~S}$ vs $\delta^{15} \mathrm{~N}$ is not shown as the 2 plots listed above were sufficient for interpretation of the data. Our discussion is centered on the plot employing $\delta^{13} \mathrm{C}$ and $\delta^{34} \mathrm{~S}$ values (Fig. 4), the most reliable indicators for sources of ingested and assimilated organic matter, since isotope shifts of +4 to $+5 \%$ may occur during

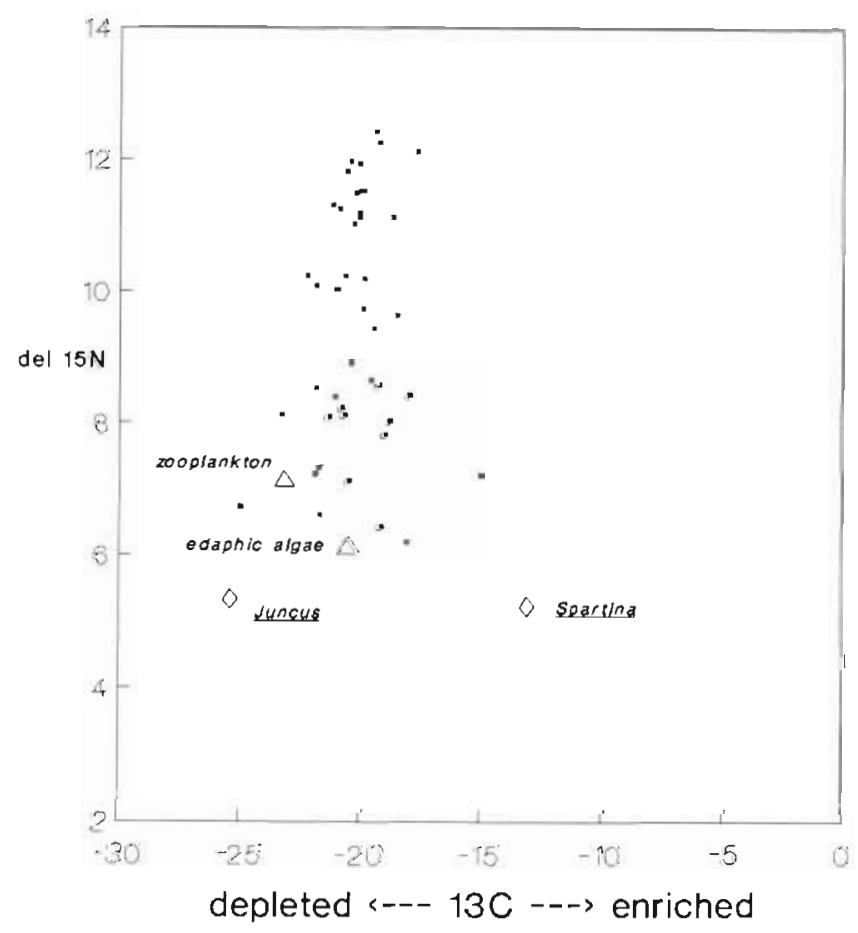

Fig. 5. Plot of $\delta^{13} \mathrm{C}$ vs $\delta^{15} \mathrm{~N}$ values for primary producers and consumers in Graveline Bay Marsh in parts per mil (\%o)

assimilation of nitrogen (Peterson \& Howarth 1987. Fry 1988).

Data points in the $\delta^{13} \mathrm{C}$ vs $\delta^{34} \mathrm{~S}$ plot (Fig. 4) cluster tightly around the edaphic algae and zooplankton. None of the consumers even moderately resemble the $\delta^{13} \mathrm{C}$ and $\delta^{34} \mathrm{~S}$ values for either Spartina or Juncus. The 
single data point near Juncus is that for the freshwater largemouth bass Micropterus salmoides, a non-resident species. Only 3 consumers (Paleomonetes pugio, Fundulus pulvereus, and $F$. majalis) appeared to exhibit any displacement toward Spartina (Fig. 4). These species are characteristically found in shallower areas well within the marsh where bacterial degradation of Spartina may affect the stable isotope ratios of available pools of organic matter. Neglecting these consumers, the distribution of $\delta^{13} \mathrm{C}$ and $\delta^{34} \mathrm{~S}$ values indicated that consumers in the Graveline system for the most part closely match the $\delta^{13} \mathrm{C}$ and $\delta^{34} \mathrm{~S}$ values of the benthic algae and zooplankton. UCa spp. (fiddler crabs) were nearly $6 \%$ more enriched in $\delta^{13} \mathrm{C}$ than the edaphic algae; however, their $\delta^{34} \mathrm{~S}$ value of $+15 \%$ almost exactly matched that of edaphic algae and was more than $13 \%$ higher than the mean $\delta^{34} \mathrm{~S}$ value of Spartina. The algal-grazing marsh periwinkle Littorina irrorata differed from the edaphic algae only in its $\delta^{13} \mathrm{C}$ value, which was only $1 \%$ less.

The $\delta^{13} \mathrm{C}$ vs $\delta^{15} \mathrm{~N}$ plot (Fig. 5) is less amenable to interpretation because the $\delta^{15} \mathrm{~N}$ values of the primary producers differ by less than $1 \%$ (Table 1). It does, however, show the tight clustering of $\delta^{13} \mathrm{C}$ values around the edaphic algae and zooplankton and hence corroborates the results shown in Fig. 4.

\section{DISCUSSION}

\section{Stable isotope ratios of producers}

The $\delta^{13} \mathrm{C}$ values of Spartina and Juncus fell within previously reported ranges. However, edaphic algae in Graveline Bay Marsh were more depleted in ${ }^{13} \mathrm{C}$ than previously reported with a $\delta^{13} \mathrm{C}$ value of $-21 \%$. Haines (1976a) measured values of -18 to $-16 \%$ for mudflat algae in a Georgia salt marsh. Peterson \& Howarth (1987) reported a value of $-17 \%$ for creekbank algae in a Georgia marsh, whereas Rodelli et al. (1984) found ranges of -20 to $-18 \%$ for 4 benthic diatom species and -22 to $-18 \%$ for filamentous green algae attached to the roots of Malaysian mangroves. Craft et al. (1988) measured $\delta^{13} \mathrm{C}$ values of -19 to $-14 \%$ for benthic and floating algae in a North Carolina salt marsh.

As previously mentioned, a pure zooplankton sample was obtained which had a $\delta^{13} \mathrm{C}$ value of $-23 \%$. Gearing et al. (1984) found from extensive sampling in Narragansett Bay that the zooplankton were enriched in ${ }^{13} \mathrm{C}$ relative to phytoplankton by $0.6 \%$. If this is also the case in the Mississippi marsh then the phytoplankton would be $-24 \%$. The filter-feeding bivalves (Polymesoda caroliniana, Rangia cuneata, Ischadium recurvum, Geukensia demissa and Crassostrea virginica) exhibited a very narrow range of -22 to $-21 \%$; this range is slightly more enriched in ${ }^{13} \mathrm{C}$ than the zooplankton in the Graveline system and approximately the same as that of phytoplankton in most estuarine systems (Gearing et al. 1984).

The average $\delta^{34} \mathrm{~S}$ value for Spartina $(+1.4 \%)$ in Graveline Bay Marsh fell amongst mean values measured by Peterson and co-workers $(1985,1986,1987)$, which ranged from -4 to $+1 \%$ in Massachusetts and Georgia salt marshes. A single value of $+6 \%$ for Juncus is all that existed before the present study (Peterson \& Howarth 1987). Juncus in Graveline Bay Marsh had an average $\delta^{34} \mathrm{~S}$ value of $+0.4 \%$. Edaphic algae with their value of $+14 \%$ compared favorably to $\delta^{34} \mathrm{~S}$ values of +13 and $+18 \%$ measured by Peterson et al. (1986) for filamentous blue-green algal mats in a Massachusetts salt marsh. These algae must therefore obtain most of their sulfur as seawater sulfate which has a $\delta^{34} \mathrm{~S}$ value of $+20 \%$ rather than as depleted sulfides which typically range from -30 to $-10 \%$. Zooplankton were $+11 \%$ which is much lower than the values of +19 and $+20 \%$ measured by Peterson et al. $(1985,1986)$. All detritus was hand-picked from the zooplankton sample so the question naturally arises as to whether or not phytoplankton in the Graveline system are more depleted in ${ }^{34} \mathrm{~S}$ than their Atlantic counterparts. A pure phytoplankton sample was not collected in the present study but the filter-feeding bivalves in the marsh were only slightly enriched in ${ }^{34} \mathrm{~S}$ relative to the zooplankton (range $=+11$ to $+12.5 \%$ for 4 species and +14 for the oyster, see Table 2). This suggests that the $\delta^{34} \mathrm{~S}$ value for the zooplankton may be very close to that actually characterizing the phytoplankton in the Graveline system, despite its low $\delta^{34} \mathrm{~S}$ value.

Stable nitrogen isotope values for Spartina and Juncus were within previously reported ranges. The $\delta^{15} \mathrm{~N}$ value $(+6 \%$ ) for edaphic algae was higher than values of $+4 \%$ (Mariotti et al. 1983, Peterson \& Howarth 1987) and $+1 \%$ (Craft et al. 1988) reported in other salt marshes. The zooplankton, with their $\delta^{15} \mathrm{~N}$ value of $+7 \%$, were more depleted than the value of $9 \%$ employed by Peterson and co-workers $(1985,1986,1987)$ for phytoplankton in their stable isotope work. Presumably the phytoplankton in the Graveline system should have a $\delta^{15} \mathrm{~N}$ value equal to or less than that of the edaphic algae.

\section{Stable isotope ratios of consumers}

Consumers collected in Graveline Bay Marsh were more depleted in ${ }^{13} \mathrm{C}$ than their counterparts in a Massachusetts (Great Sippewissett) and Georgia (Sapelo Island) salt marsh. Forty-nine of the $56(88 \%)$ consumers listed in Table 2 (see also Fig. 1) had $\delta^{13} \mathrm{C}$ values between -22 and $-18 \%$. Of these 49 consumers, 34 fell within a narrower range of -22 to $-20 \%$. At 
Great Sippewissett, $\delta^{13} \mathrm{C}$ values for the marsh fauna fell between -17 and $-10 \%$ (Peterson et al. 1986), while in Sapelo Island the range for consumers was -18 to $-15 \%$ (Peterson \& Howarth 1987). The $\delta^{13} \mathrm{C}$ values of the Mississippi consumers therefore do not even overlap those of their counterparts in the 2 Atlantic salt marshes. With few exceptions, all consumers were more enriched in ${ }^{13} \mathrm{C}$ than zooplankton and their $\delta^{13} \mathrm{C}$ values centered around that for the edaphic algae (Fig. 1). As previously mentioned, $\delta^{13} \mathrm{C}$ for all benthic algae in the Graveline system ranged from -21 to $-18 \%$, which would include the majority of values for consumers.

A word of caution must be expressed when making comparisons with the stable carbon isotope work of Peterson and co-workers $(1985,1986,1987)$ as Spartina was the dominant vascular plant with Juncus a minor component of the flora in their studies. In Graveline Bay Marsh Juncus is predominant but Spartina nevertheless still contributes significantly to total marsh production. Another important point is that many of the animals collected in the present study were subtidal species. It is thus worthwhile to compare our results with those of Hughes \& Sherr (1983), who examined $\delta^{13} \mathrm{C}$ values of subtidal consumers from tidal creeks draining either Spartina- or Juncus-dominated marshes in Georgia. Seven invertebrates and 11 fish were sufficiently similar, i.e. same species or genus or ecological niche, for comparisons to be made. The average $\delta^{13} \mathrm{C}$ value of subtidal consumers of this study was -20.5 , while values of -20.3 and $-18.1 \%$ were found by Hughes \& Sherr for subtidal consumers of Juncus and Spartina tidal creeks, respectively. Thus, the specific identity of the dominant vascular plant may influence the $\delta^{13} \mathrm{C}$ of resident consumers. It should be mentioned, however, that the Juncus-dominated creeks studied by Hughes \& Sherr were more influenced by freshwater flow than was the Spartina creek, and this may have been a factor in explaining the observed differences.

The consumers in Graveline Bay Marsh were slightly more enriched in ${ }^{34} \mathrm{~S}$ than their counterparts from a Georgia salt marsh. Forty-eight of the Mississippi consumers ( $86 \%$ of total) fell within a range of +9 to $+16 \%$ (Table 2, Fig. 2). Most of the marsh fauna at Sapelo Island had $\delta^{34} \mathrm{~S}$ values between +6 and $+14 \%$ (Peterson \& Howarth 1987). Among the consumers with the highest $\delta^{34} \mathrm{~S}$ values were Uca spp., Littorina irrorata, and Crassostrea virginica; this was also true in our study. Peterson \& Howarth considered it unlikely that phytoplankton were the main source of sulfur for Uca spp. and L. irrorata but that edaphic and epiphytic algae, which also obtain most of their sulfur from seawater sulfate, were their major ultimate source of organic matter This is also probably true of the majority of consumers in the Graveline system, as $86 \%$ of all consumers were 8 to $15 \%$ more enriched in ${ }^{34} \mathrm{~S}$ than Spartina. Finally, Peter- son et al. (1986) found that all fauna in the Great Sippewissett salt marsh had $\delta^{34} \mathrm{~S}$ values between 0 and $10 \%$. Such values are intermediate between those for Spartina and for benthic and planktonic algae.

The only other study in which comprehensive $\delta^{15} \mathrm{~N}$ measurements were made is that of Peterson \& Howarth (1987) in the salt marshes of Sapelo Island. They observed that the $\delta^{15} \mathrm{~N}$ values for consumers $(+7$ to $+11 \%$ ) centered around the phytoplankton (+9\%o). In Graveline Bay Marsh, virtually all consumers $(+6$ to $+12 \%$ ) were enriched in ${ }^{15} \mathrm{~N}$ compared to the vascular plants $(+5 \%)$ and edaphic algae $(+6 \%)$, and all but 3 consumers were enriched relative to the zooplankton $(+7 \%)$. Peterson \& Howarth (1987) found that fiddler crabs (Uca spp.) and small mullet (Mugil cephalus) generally had the lowest $\delta^{15} \mathrm{~N}$ values which was also true in our study.

Stable nitrogen isotope ratios are good indicators of trophic level whereas those of carbon and sulfur are not (Fry 1988). Peterson \& Howarth (1987) found that consumers fractionate nitrogen by +1 to $+5 \%$ per trophic transfer; fractionation of carbon or sulfur was slight and could be in either the positive or negative direction (see their Table 3). Peterson \& Howarth divided the marsh fauna of Sapelo Island into 2 groups: one with $\delta^{15} \mathrm{~N}$ values less than $9 \%$ which included deposit and suspension feeders, and a second with $\delta^{15} \mathrm{~N}$ values greater than $9 \%$ which included predators and omnivores. Consumers belonging to the deposit/suspension feeding group were UCa spp., small Mugil cephalus (small mullet), Geukensia demissa, Littorina irrorata, and Crassostrea virginica. Consumers belonging to the predator/omnivore group were Paleomonetes pugio, Pennaeus setiferus, Bairdiella chrysura, Callinectes sapidus, Fundulus heteroclitus, and large Mugil cephalus. Such an arbitrary division would seem also to characterize the fauna of Graveline Bay Marsh quite well (see Table 2). The 5 filterfeeding bivalves belong to the first group as do Uca spp., Neanthes spp., and the bryozoans Anguinella palmata and Bugula sp. C. sapidus and $P$. pugio had $\delta^{15} \mathrm{~N}$ values very close to $9 \%$; however, both species are highly omnivorous and thus utilize a variety of food sources. All fish species except Pogonias cromis, Poecilia latipinna, and Fundulus pulvereus fall into the second predator/ omnivore group based on their $\delta^{15} \mathrm{~N}$ values which is generally consistent with their biology. Thus, $\delta^{15} \mathrm{~N}$ measurements appear to be an excellent indicator of a consumer's relative trophic level in the Mississippi marsh.

\section{Dual isotope plots}

In sharp contrast to previous studies (Peterson et al 1986, Peterson \& Howarth 1987), plots employing $\delta^{13} \mathrm{C}$ and $\delta^{34} \mathrm{~S}$ values or $\delta^{13} \mathrm{C}$ and $\delta^{15} \mathrm{~N}$ values of primary 
producers and consumers did not result in a broad band of values lying between phytoplankton and Spartina. Instead, this dual isotope procedure for Graveline Bay Marsh produced a tight clustering of data points around the edaphic algae and zooplankton (Fig. 4 and 5). Consumers varied from moderately to greatly depleted in ${ }^{13} \mathrm{C}$ and enriched in ${ }^{34} \mathrm{~S}$ relative to Spartina. The marsh periwinkle Littorina irrorata, which is known to graze on edaphic algae, was essentially identical to the latter in both its $\delta^{13} \mathrm{C}$ and $\delta^{34} \mathrm{~S}$ values. The one outlier in this plot, the freshwater bass Micropterus salmoides, was only collected once at the periphery of the marsh system; it serves primarily to illustrate the discrete separation of the Graveline system from any bordering freshwater systems. A reasonable conclusion from the stable isotope data is that the major food sources for the fauna of Graveline Bay Marsh are the edaphic and planktonic algae; the contribution of vascular plants appears to be minor. This does not mean of course that all consumers are actually eating algae, but that the algae are the major basis of the food web in Graveline Bay Marsh. Kitting et al. (1984) used stable carbon isotope analysis to show that epiphytic algal carbon, rather than that of seagrasses, formed the primary basis of the food web in Texas seagrass beds; very little of the seagrass leaf biomass was ingested by any invertebrate species.

There is an alternative interpretation of the data. Observed $\delta^{13} \mathrm{C}$ values for consumers in Graveline Bay Marsh could be due to ingestion of Juncus and other vascular plant detritus. It is possible that heterotrophic microorganisms degrading mineral-poor, i.e. high C: N : S ratio, plant detritus could take up their nitrogen and sulfur from the water column. Their $\delta^{15} \mathrm{~N}$ and $\delta^{34} \mathrm{~S}$ values would then resemble those of the algae while their $\delta^{13} \mathrm{C}$ value would be similar to that of the vascular plant (Juncus $=-26 \%$ ). Recent work in salt marsh tidal creeks has suggested that a major carbon pathway may exist from heterotrophic bacteria to protozoa (Sherr et al. 1989). Such protozoans (mainly ciliates and colorless flagellates) are readily grazed by microcrustaceans and fish larvae (Sherr \& Sherr 1988). The high $\delta^{34} \mathrm{~S}$ values of the subtidal fauna of Graveline Bay Marsh argue for an algal-based food web, but in the absence of data on the abundance of Juncus detritus and stable isotope composition of its bacterial decomposers, the possibility discussed above cannot be discounted.

It is not possible to evaluate the relative importance of edaphic algae and phytoplankton since their $\delta^{13} \mathrm{C}$ values are so close and the $\delta^{34} \mathrm{~S}$ value of the latter in Graveline Bay Marsh is not precisely known. Furthermore, the stable isotope values for edaphic algae are based on a single composite sample. One therefore, cannot be sure how representative these values are, both temporally and spatially. What is evident, however, is that this represents the first study to show that vascular plant carbon may be of little direct trophic importance in at least some marsh systems, although the alternative hypothesis discussed above cannot be discounted. Hopefully, the data presented here will encourage other investigators to consider the benthic algae as a potentially important source of organic matter in future studies of trophic relationships in salt marshes and other estuarine systems. This becomes even more important when one considers that a significant proportion of water column productivity, i.e. 'planktonic' productivity, in shallow estuarine systems may sometimes be due to displaced benthic diatoms and other microalgae (Riaux-Gobin 1987, Shaffer \& Sullivan 1988).

\section{Regional comparisons}

The only other studies employing multiple stable isotopes in salt marshes are those of Peterson et al. (1986) for Great Sippewissett Marsh in Massachusetts and Peterson \& Howarth (1987) for Sapelo Island marshes in Georgia. The present study makes possible a comparison of a Gulf Coast marsh with 2 widely separated Atlantic marshes. It is profitable to begin with a comparison of the stable isotope values of consumers listed in both Table 2 of the present study and Table 4 of Peterson \& Howarth (1987). All but one (UCa sp.) of the 11 species common to both studies were more depleted in ${ }^{13} \mathrm{C}$ in the Mississippi marsh. The Graveline Bay Marsh fauna was on average $2.7 \%$ more depleted than Sapelo Island fauna $\left(\delta^{13} \mathrm{C}\right.$ means $=-19.8$ and $-17.1 \%$, respectively). The opposite was true for $\delta^{34} \mathrm{~S}$; all but one (Paleomonetes pugio) Mississippi consumer were more enriched in ${ }^{34} \mathrm{~S}$ than the same species in Georgia. The average enrichment was $2.1 \%$ ( $\delta^{34} \mathrm{~S}$ means $=+11.6$ and $+9.5 \%$, respectively). As previously mentioned, these differences in $\delta^{13} \mathrm{C}$ and $\delta^{34} \mathrm{~S}$ may be due to the dominance of Spartina in Georgia and Juncus in Mississippi, or to freshwater influences. The average $\delta^{15} \mathrm{~N}$ value for these consumers was 8.9 and $8.4 \%$ in Mississippi and Georgia, respectively. The difference is only $0.5 \%$, which probably does not represent a significant enrichment and agrees with previous findings (Fry 1988) that $\delta^{15} \mathrm{~N}$ is most useful as an indicator of trophic level rather than food source.

As one moves from Massachusetts to Georgia to Mississippi, the following trends confront an observer (see also Table 5 of Peterson \& Howarth 1987): (1) $\delta^{13} \mathrm{C}$ values for Spartina stay constant at $-13 \%$ whereas those for edaphic algae (and perhaps phytoplankton) become increasingly more negative; (2) the 
marsh fauna becomes increasingly depleted in ${ }^{13} \mathrm{C}$ and increasingly enriched in ${ }^{34} \mathrm{~S}_{\text {; }}$ and (3) although $\delta^{15} \mathrm{~N}$ values for consumers increase slightly the differences are insignificant compared to those for carbon and sulfur. Peterson \& Howarth (1987) interpreted these trends as indicating that consumers in the Sapelo Island marshes were more dependent on phytoplankton and perhaps benthic algae than the fauna at Great Sippewissett. They stated that the contributions of Spartina and algae to the food web at Sapelo Island were 'roughly equal' whereas their previous isotope work (Peterson et al. 1986) at Sippewissett led to the conclusion that Spartina was the major food source but phytoplankton were also important. The benthic algae were not considered in their earlier study. In the Mississippi marsh we move more or less 180 degrees from the conclusions of the Sippewissett study in that planktonic and benthic algae are major food sources and the vascular plants presumably play a minor role.

Why the relative importance of algae and vascular plants should change so dramatically as one moves south along the Atlantic Coast and then west to the Gulf Coast is an important question, since it relates to possible differences in the functioning of salt marshes from different geographical regions. Peterson \& Howarth (1987) hypothesized that algae would be expected to be more important in Georgia than in Massachusetts if their productivity and availability relative to Spartina were higher in the more southerly marsh. The productivity rates of edaphic algae on the marsh proper (Sullivan \& Moncreiff 1988) and in the subtidal sediments of Graveline Bayou and lowerorder tidal creeks (Zimba unpubl. data) are significant but are less than those measured by Pomeroy (1959) in Sapelo Island marshes. These algae are known to be the preferred food source for a host of estuarine consumers at lower trophic levels including harpacticoid copepods, nematodes, ostracods, mollusks, juvenile shrimp, and certain fish species (Gleason and Zimmerman 1984, Montagna 1984, Gleason 1986, PlanteCuny \& Plante 1986, Decho 1988). It should be pointed out that in addition to the relative dominance of Spartina vs Juncus, there are differences in basic hydrology between the 3 systems discussed above. Such differences include tidal range, regularity of tidal flooding, and possible freshwater and upland terrestrial inputs. Factors of this type could also be key components leading to the observed differences in stable isotope ratios. In addition, climatic factors affecting rates of biological activity and seasonal changes within each system may contribute to the observed regional shifts in isotopic ratios. However, the bottom line is that benthic algae should not be ignored in estuarine food web studies.
Acknowledgements. Many long but memorable hours were spent in the field collecting plants, animals, detritus, and mud These collecting efforts would not have been successful without the expert boat-handling skills and labors of Bill Demoran, John Cirino, and Steve Breland. Stacy Spencer spent many hours removing detritus from zooplankton samples. This work is a result of research sponsored in part by NOAA Office of Sea Grant, Department of Commerce under Grant \#NA85AA-D-SG005, the Mississippi-Alabama Sea Grant Consortium and Mississippi State University. The U.S. Government is authorized to produce and distribute reprints for governmental purposes notwithstanding any copyright notation that may appear hereon.

\section{LITERATURE CITED}

Craft, C. B., Broome, S. W., Seneca, E. D., Showers, W J. (1988). Estimating sources of soil organic matter in natural and transplanted estuarine marshes using stable isotopes of carbon and nitrogen. Estuar. cstl Shelf Sci. 26: 633-641

Decho, A. W (1988). How do harpacticoid grazing rates differ over a tidal cycle? Field verification using chlorophyll pigment analysis. Mar. Ecol. Prog. Ser. 45: 263-270

Fry, B. (1988). Food web structure on Georges Bank from stable $\mathrm{C}, \mathrm{N}$, and $\mathrm{S}$ isotopic compositions. Limnol. Oceanogr. 33: 1182-1190

Fry, B., Scalan, J. K., Winters, J. K., Parker, P. L. (1982) Sulphur uptake by salt grasses, mangroves, and seagrasses in anaerobic sediments. Geochim. cosmochim. Acta 46: 1121-1124

Fry, B., Sherr, E. B. (1984). $\delta^{13} \mathrm{C}$ measurements as indicators of carbon flow in marine and freshwater ecosystems. Contr. mar. Sci. Univ. Tex. 27: 13-47

Gearing, J. N., Gearing, P. J., Rudnick, D. T., Requejo, A. G. Hutchins, M. J. (1984). Isotopic variability of organic carbon in a phytoplankton-based, temperate estuary. Geochim. cosmochim. Acta 48: 1089-1098

Gleason, D. F. (1986). Utilization of salt marsh plants by postlarval brown shrimp: carbon assimilation rates and food preferences. Mar Ecol. Prog. Ser. 31: 151-158

Gleason, D. F., Zimmerman, R. J. (1984). Herbivory potential of postlarval brown shrimp associated with salt marshes. $J$. exp. mar Biol. Ecol. 84: 235-246

Hackney, C. T., Haines, E. B. (1980). Stable carbon isotope composition of fauna and organic matter collected in a Mississippi estuary. Estuar. cstl Mar. Sci. 10: 703-708

Haines, E. B. (1976a). Stable carbon isotope ratios in the biota, soils and tidal water of a Georgia salt marsh. Estuar cstl Mar. Sci. 4: 609-616

Haines, E. B. (1976b). Relation between the stable carbon isotope composition of fiddler crabs, plants, and soils in a salt marsh. Limnol. Oceanogr. 21 880-883

Haines, E. B. (1977). The origins of detritus in Georgia salt marsh estuaries. Oikos 29: 254-260

Haines, E. B., Montague, C. L. (1979). Food sources of estuarine invertebrates analyzed using ${ }^{13} \mathrm{C} /{ }^{12} \mathrm{C}$ ratios. Ecology 60: 48-56

Hughes, E. H., Sherr, E. B. (1983). Subtidal food webs in a Georgia estuary: $\delta^{13} \mathrm{C}$ analysis. J. exp. mar Biol. Ecol. 67 : $227-242$

Jackson, D., Harkness, D. D., Mason, C. F., Long, S. P. (1986). Spartina anglica as a carbon source for salt-marsh invertebrates: a study using $\delta^{13} \mathrm{C}$ values. Oikos 46: $163-170$

Kitting, C. L., Fry, B., Morgan, M. D. (1984). Detection of inconspicuous epiphytic algae supporting food webs in seagrass meadows. Oecologia 62: 145-149 
Mariotti, A., Letolle, R., Sherr, E. B. (1983). Distribution of stable nitrogen isotopes in a salt marsh estuary. Estuaries 6: 304

Montagna, P. A. (1984). In situ measurement of meiobenthic grazing rates on sediment bacteria and edaphic diatoms. Mar. Ecol. Prog. Ser 18: 119-130

Peterson, B. J., Howarth, R. W (1987). Sulfur, carbon, and nitrogen isotopes used to trace organic matter flow in the salt-marsh estuaries of Sapelo Island, Georgia. Limnol. Oceanogr. 32: 1195-1213

Peterson, B. J., Howarth, R. W., Garrit, R. H. (1985). Multiple stable isotopes used to trace the flow of organic matter in estuarine food webs. Science, N.Y. 227: 1361-1363

Peterson, B. J., Howarth, R. W., Garrit, R. H. (1986). Sulfur and carbon isotopes as tracers of salt-marsh organic matter flow. Ecology 67: 865-874

Plante-Cuny, M.-R., Plante, R. (1986). Benthic marine diatoms as food for benthic marine animals. In: Ricard, M. (ed.) Proc. 8th int. Diatom Symp., Paris, 1984. S. Koeltz, Königstein, p. 525-537

Pomeroy, L. R. (1959). Algal productivity in salt marshes of Georgia. Limnol. Oceanogr. 4: 386-397

Riaux-Gobin, C. (1987). Phytoplancton, tripton et microphytobenthos: échanges au cours de la marée, dans un estuaire du Nord-Finistère. Cah. Biol. mar. 28: 159-184.

This article was submitted to the editor
Rodelli, M. R., Gearing, J. N., Gearing, P. J., Marshall, N., Sasikumar, A. (1984). Stable isotope ratio as a tracer of mangrove carbon in Malaysian ecosystems. Oecologia 61 : 326-333

Schwinghamer, P., Francis, C. T., Gordon, D. C. (1983). Stable carbon isotope studies on the Pecks Cove mudflat ecosystem in the Cumberland Basin, Bay of Fundy. Can. J. Fish. Aquat. Sci. 40 (Suppl.): 262-272

Shaffer, G. P. Sullivan, M. J. (1988). Water column productivity attributable to displaced benthic diatoms in well-mixed shallow estuaries. J. Phycol. 24: 132-140

Sherr, B. F., Sherr, E. B., Pedrós-Alió, C. (1989). Simultaneous measurement of bacterioplankton production and protozoan bacterivory in estuarine water. Mar. Ecol. Prog. Ser. 54: $209-219$

Sherr, E. B. (1982). Carbon isotope composition of organic seston and sediments in a Georgia salt marsh estuary. Geochim. cosmochim. Acta 46: 1227-1232

Sherr, E. B., Sherr, B. F. (1988). Role of microbes in pelagic food webs: a revised concept. Limnol. Oceanogr. 33: 1225-1227

Sullivan, M. J., Moncreiff, C. A. (1988). Primary production of edaphic algal communities in a Mississippi salt marsh. J. Phycol. 24: 49-58

Zedler, J. B. (1980). Algal mat productivity: comparisons in a salt marsh. Estuaries 3: 122-131

Manuscript first received: August 11, 1989

Revised version accepted: January 12, 1990 